\title{
Corporate Governance Variables and Integrated Reporting
}

\author{
Arcangelo Marrone ${ }^{1}$ \\ ${ }^{1}$ Department of Economics and Management, University LUM Jean Monnet, Italy \\ Correspondence: Arcangelo Marrone, Department of Economics and Management, University LUM Jean Monnet, \\ Casamassima (BA), Italy. E-mail: marrone@lum.it
}

Received: February 26, 2019

Accepted: March 28, 2020

Online Published: April 8, 2020

doi:10.5539/ijbm.v15n5p26

URL: https://doi.org/10.5539/ijbm.v15n5p26

\begin{abstract}
Integrated reporting (IR) represents the last frontier of corporate disclosure. Its purpose is to provide information on an organization's strategy and its business model, performance and governance, offering a clear overview of the organization's capacity to create value. From an academic point of view, the focus on integrated reporting has grown significantly in recent years. However, an aspect still little explored is represented by the level of compliance of the integrated reports with the IIRC requirements. Among the few studies on the issue of the level of alignment of integrated reports with the IIRC framework, only two focused on identifying the determinants. This work aims to bridge this gap through the analysis of the effect of three characteristics of the board (size, average age, gender diversity) and one of the CEO (duality) on the level of compliance of integrated reports with the IIRC framework. The results show a significant and positive effect of board size and board gender diversity on the level of alignment of integrated reports with the IIRC framework. They also show a significant and negative effect of the CEO duality and a not significant effect of the board average age.
\end{abstract}

Keywords: integrated reporting, board of directors, disclosure, corporate governance

\section{Introduction}

This work aims to provide some empirical considerations on the role of corporate governance variables in integrated reporting policies. Integrated reporting (IR), conceived by the International Integrated Reporting Council (IIRC), originates from the integrated management of resources (integrated thinking), aimed at supporting the company's search for value creation (Vitolla et al., 2019a). Integrated reporting naturally takes the form of preparing a report for external communication, the main objective of which is to assemble non-financial and financial information in an interconnected way, in order to help stakeholders express their opinion on the performance of the organization and its creation of value over time (Porter \& Kramer, 2011). Integrated reporting has also the objective of guiding organizations to be responsible and to legitimize their role in the environment in which they operate, taking into consideration not only profit maximization, but also the realization of adequate non-financial performances (Vitolla et al., 2019b).

In this perspective, the integrated report therefore represents, on the one hand, a support tool for systemic management and, on the other, the response to the need for information from stakeholders (D'Este et al., 2013). The central idea of the IIRC framework is that organizations must include information about all the resources used and all the results obtained in their integrated report. Therefore, the IIRC framework introduces six different capitals (manufactured, financial, natural, intellectual, social and relationship, human) which represent the inputs and outcomes of corporate management (IIRC, 2013).

From an academic perspective, the focus on integrated reporting has grown significantly in recent years (Vitolla et al., 2018; Vitolla et al., 2019c). Existing empirical contributions have mainly analysed the effects (Mervelskemper \& Streit, 2017; Barth et al., 2017; Vitolla \& Raimo, 2018; Esch et al., 2019; Vitolla et al., 2020a) and the antecedents of integrated reporting (Jensen \& Berg, 2012; Gerwanski et al., 2019; Frías-Aceituno et al., 2013a; 2014; Vitolla et al., 2019d; 2020b). These studies, however, focused exclusively on the adoption of this tool or on the quality of the information provided. An aspect still little analysed is represented by the level of alignment of the integrated reports with the IIRC framework (Marrone \& Oliva, 2019). The alignment of the reports with the IIRC requirements, favouring the standardization of the contents, could facilitate the reading and understanding of the documents to investors and to all stakeholders (Marrone \& Oliva, 2019). Furthermore, compliance with the IIRC framework by allowing a comparison between the reports of different companies and favouring the search for key 
content, could favor the understanding of investors and all the stakeholders of the different business realities (Marrone \& Oliva, 2020). These circumstances underline the importance of the level of alignment of the reports and highlight how this aspect differs from the simple integrated reporting adoption and from the quality of the information contained within the reports.

However, despite the relevance of this aspect, the level of alignment of the integrated reports with the IIRC requirements is still little explored in the literature. This important gap makes it necessary to analyse the level of compliance with the IIRC framework. This work aims to identify the antecedents of the compliance level, with particular reference to the corporate governance variables, represented by the characteristics of the CEO and the board. In fact, both the board and the CEO play a particularly important role in corporate communication policies (Healy, 2002; Perrini, 2006; Muttakin et al., 2018). In an agency theory key (Jensen \& Meckling, 1976) they represent a control mechanism that allows to align the interests of shareholders and management.

However, despite the importance of the role played by the corporate governance variables, there are no studies analysing the effects on the level of alignment of the integrated reports with the IIRC requirements. This work aims to bridge this gap through the analysis of the effects of three features of the board (size, average age, gender diversity) and one of the CEO (duality) on the level of compliance of integrated reports with the IIRC framework.

\section{Literature Review}

A lot of studies have analysed the relationship existing between corporate governance and integrated reporting. A part of the studies has analysed the role of the performance of the governance system on the decision to publish an integrated report and on the quality of the information contained within the the documents in terms of balance, completeness and conciseness (Melloni et al., 2017). In this perspective, Lai et al. (2016) showed a positive impact of governance performance on the choices to adopt integrated reporting, while Melloni et al. (2017) found no relationship between corporate governance performance and the quality of information provided in the integrated reports.

Going beyond the aspects connected to governance performance, the existing contributions have mainly analysed the role of three bodies: board of directors, audit committee and sustainability committee.

The board of directors has the task of monitoring the activities of the managers in order to maximize the shareholders interests (Ben-Amar \& Mcllkenny, 2015). The literature has mainly analysed the characteristics of the directors able to influence the effectiveness of the monitoring of the board with reference to the integrated reporting. A first aspect analysed by the contributions in the literature is represented by the board diversity. In this perspective, part of the studies analysed gender diversity (Fasan \& Mio, 2017; García -Sánchez \& Noguera-Gámez, 2018; Frias-Aceituno et al., 2013b; Alfiero et al., 2017; Kilic \& Kuzey, 2018; Gerwanski et al., 2019; Vitolla et al., 2020b) while another part analysed foreign diversity and age diversity (Frias-Aceituno et al., 2013b; Alfiero et al., 2017). With regards to the gender diversity, Frias-Aceituno et al. (2013b) underlined a positive effect of the female directors on the propensity of the firm to publish an integrated report. Vitolla et al. (2020b) found a positive effect of the gender diversity on the integrated reporting quality. Kilic and Kuzey (2018) instead emphasized how gender diversity positively impacts the presence of forward-looking information in integrated reports. Gerwanski et al. (2019), also showed that the presence of female directors increases the material disclosure quality, while Fasan and Mio (2017) underlined an opposite finding thus underlining a negative effect. With regards to the foreign diversity, Frias-Aceituno et al. (2013b) underlined how foreign members on the board have no effect on the choice of publishing an integrated report. Finally, Alfiero et al. (2017), with regard to the age diversity, pointed out that companies with boards of directors that contain old directors have a lower propensity to adopt integrated reporting.

Another aspect analysed by the literature is the board independence (Stacchezzini et al., 2016; Fasan \& Mio, 2017; Kilic \& Kuzey, 2018). Stacchezzini et al. (2016) highlighted that the integrated reports of firms with less independent boards are more focused on sustainability actions than sustainability performances while Vitolla et al. (2020b) found that board independence increases integrated reporting quality.

Starting from the assumption that a greater number of directors and a greater number of meetings, increasing dialogue and comparison, lead to better decisions, some previous studies analysed the impact of the board size (Frias-Aceituno et al., 2013b; Alfiero et al., 2017; Fasan \& Mio, 2017; Kilic \& Kuzey, 2018) and of the board level of activity (Fasan \& Mio, 2017) on integrated reporting. In relation to this last aspect, the results verified the presence of a positive and significant relationship between the number of board meetings and the integrated reporting quality (Vitolla et al., 2020b). Instead, in relation to the board size, both Alfiero et al. (2017) and Frias-Aceituno et al. (2013b) showed that larger boards favor the integrated reporting adoption, Vitolla et al. (2020b) showed that board size increases integrated reporting quality, while Fasan and Mio (2017) underlined a negative effect of the dimension of the board on the materiality disclosure quality. 
Although the audit committee plays a central role in risk management and reporting processes (Ahmed Haji \& Anifowose, 2016), only two studies have analysed its effects on integrated reporting. In this regard, Velte (2018) focused on the expertise of the audit committee, underlining how financial and sustainability skills increase the level of readability of integrated reports. Ahmed Haji and Anifowose (2016) instead examined the impact of the activity level and the authority and effectiveness of the audit committee, finding a positive effect on the amount of information contained in the integrated reports and with the level of compliance with the principles dictated by the IIRC.

A further aspect analysed by the literature is represented by the presence of a sustainability committee that could increase the company's propensity to develop environmental and social initiatives. In this regard, Ahmed Haji and Anifowose (2016) showed how the presence of a CSR committee favours the publication of more complete documents more closely aligned with the IIRC framework.

The literature review carried out shows the absence of contributions on the influence of the corporate governance variables on the level of alignment of the integrated reports with the IIRC requirements. This work aims to fill this gap through the analysis of the impact of the features of the board and CEO on the level of compliance of the integrated reports with the IIRC framework.

\section{Hypothesis Development}

Jensen and Meckling (1976) introduced a theoretical framework according to which substitutive or complementary links were established between disclosure policies of firms and their corporate governance systems. According to the complementary relationship, effective corporate governance strengthens the internal control of the company thus favouring the disclosure of information in order to reduce information asymmetry and opportunistic behavior. On the contrary, according to the substitutive relationship, the corporate governance strength reduces or prevents the provision of information due to internal control mechanisms reliability. This study, in line with previous contributions on the topic of integrated reporting (Vitolla et al., 2020b; Frias- Aceituno et al., 2013b) assumes a complementary relationship between corporate governance systems and the alignment of integrated reports with the IIRC framework.

Board size. Control and monitoring are the main activities carried out by the board of directors (Fama \& Jensen, 1983). In this regard, an increase in the number of directors increases the board's ability to perform these functions (Gandia, 2008). This fact in fact improves transparency and consequently the disclosure policies of companies (Vitolla et al., 2020b). Furthermore, according to the resource dependence theory, the larger boards bring more intellectual resources (Kosnik, 1990; Pfeffer \& Salancik, 1978; Parum, 2005; Pfeffer, 1972) and present different experiences and opinions. (Adams et al., 2005). Furthermore, the larger boards present more skills and competences (Hidalgo et al., 2011). These circumstances improve the control and monitoring activities of the board (Alfiero et al., 2017). The empirical contributions underline a positive effect of the dimension of the board and the level of information disclosed by the companies (Dalton et al., 1999; Cheng \& Courtenay, 2006; Larmou \& Vafeas, 2010; Pearce \& Zahra, 1992; Izzo \& Fiori, 2016). The level of alignment of the integrated report with the IIRC framework requires inputs from members with different types of skills and experiences. It also requires a high level of control and monitoring by the board. Such circumstances are likely to be more common in larger boards of directors. Therefore, we introduce the following hypothesis:

\section{H1: Integrated reporting alignment with the IIRC framework is positively influenced by board size}

Board average age. The control and monitoring functions of the board of directors are influenced by the characteristics of the directors (Vitolla et al., 2020b). In this regard, Dahya et al. (1996) underline how the experience of the board members favours the transparency of the company since the greater knowledge of the directors increases the possibility of comparison. The more experienced members are more interested in effectively carrying out the control and monitoring functions to safeguard their reputation and to increase attractiveness in the labour market. Therefore, the members with more experience improve the board's ability to monitor the work of management (Useem, 1993; Westphal \& Milton, 2000). The directors' experience is very often closely related to age. In light of this, we assume that older members have more experience and greater control and monitoring capacity than younger members. The level of alignment of the integrated report with the IIRC framework requires inputs from directors with more experience. It also requires a high level of control and monitoring by the board. Such circumstances are likely to be more common in boards of directors with a higher average age. Therefore, we introduce the following hypothesis:

H2: Integrated reporting alignment with the IIRC framework is positively influenced by board average age Board gender diversity. Board diversity favours the consideration of different contexts, ideas and perspectives in 
the decision-making process (Post et al., 2011). Among the different types of diversity, many studies focused on gender diversity (Alfiero et al., 2017; Vitolla et al., 2019b; Frias-Aceituno et al., 2013b). Women and men present different skills, communication styles, experiences, education and personalities (Buss, 2005; Feingold, 1994). Hofstede et al. (2010) also highlighted differences in terms of values and behavioral models. Women are more involved in their activities and are more diligent and therefore encourage the creation of a positive atmosphere within the board of directors (Huse \& Solberg, 2006). Furthermore, they have a higher percentage of participation in board meetings than that of men (Huse \& Solberg, 2006). The presence of women directors on the board also brings knowledge, innovation and creativity (Watson et al., 1993). In this regard, Adams and Ferreira (2009) have highlighted that women have a positive effect on the board's inputs and outputs. In fact, women contribute to the creation of alliances and are more prepared on board matters. Empirical evidence suggests that women improve control and monitoring functions and increase the transparency and quality of corporate disclosure (Adams \& Ferreira, 2009; Srinidhi et al., 2011). The level of alignment of the integrated report with the IIRC framework requires inputs from directors with different experiences. It also requires a high level of control and monitoring by the board. Such circumstances are likely to be more common in boards of directors with a higher presence of women. Therefore, we introduce the following hypothesis:

\section{H3: Integrated reporting alignment with the IIRC framework is positively influenced by board gender diversity}

CEO duality. CEO duality, according to Fama and Jensen (1983), identifies the absence of separation of decision management and decision control. CEO duality involves a concentration of decision-making power, which reduces the board independence and its ability to control and monitor (Gul \& Leung, 2004; Finkelstein \& D'Aveni, 1994). CEO duality reduces the board's objectivity (Krishnan \& Visvanathan, 2009) due to the chairman's authority to set the agenda and select members and to hide critical information from other board members (Krishnan \& Visvanathan, 2009; Haniffa \& Cooke, 2002). Furthermore, CEO duality creates a solid individual power base that could reduce board independence. Therefore, CEO duality causes a circumstance that could adversely affect the disclosure of information. Empirical evidence shows that CEO duality has a negative impact on monitoring (Tuggle et al., 2010) and on the level of information disclosed by companies (Ho \& Wong, 2001; Giannarakis, 2014). The level of alignment of the integrated report with the IIRC framework requires a high level of control and monitoring. This circumstance is likely to be more common in the absence of CEO duality. Therefore, we introduce the following hypothesis:

\section{H4: Integrated reporting alignment with the IIRC framework is negatively influenced by CEO duality}

\section{Methodology}

\subsection{Sample}

This work comprises 139 international firms that publish an integrated report in compliance with the IIRC framework. Following Raimo et al. (2019) and Vitolla et al. (2019d), the integrated reports were selected from two section of the IIRC website: $<\mathrm{IR}>$ Reporters; Leading Practices. This circumstance guarantees that the documents are drawn up in compliance with the IIRC framework. We have selected companies randomly. The selected companies are differentiated in terms of industry, country and size. The selected companies belong to the following sectors: basic materials; communications; technology; industrial; utilities; financial; energy; consumer. In addition, the sample includes companies from the following regions: Africa; America; Asia; Europe and Oceania.

\subsection{Variables and Model Specification}

The level of alignment with the IIRC framework (IRAL) represents the dependent variable of this study. In order to measure the level of alignment of the integrated reports with the IIRC framework, this work uses the scoreboard devised by Marrone \& Oliva $(2019 ; 2020)$. It evaluates the presence within the integrated report of information connected to the fundamental concepts and to content elements (IIRC, 2013). Thus, this scoreboard evaluates the presence of 10 elements: 2 fundamental concepts and 8 content elements. The two fundamental concepts are represented by the capitals and by the value creation process. The eight content elements are: governance, organizational overview and external environment, strategy and resource allocation, business model, performance, outlook, basis of presentation, and risks and opportunities. The scoreboard analyses the presence of qualitative, quantitative and monetary information within the integrated reports. It assigns a score of 0 in the case of absence of a single element, a score of 1 in the case of, for the single element, only qualitative information was present, a score of 2 in the event that qualitative and quantitative information was present and, finally, a score of 3 in the case of the presence of qualitative, quantitative and monetary information. In light of this, the maximum score for an integrated report is 30 . 
The independent variables of this study are represented by: board size, board average age, board gender diversity and CEO duality. Board size (BS) is represented by the number of directors within the board. Board average age (BAA) is represented by the average age of board's members. Board gender diversity (BGD) is represented by the percentage of women on the board. CEO duality (DUAL) represents a dummy variable that assumes a score of 1 if the CEO is also chairman of the board and 0 in the opposite case.

We included some control variables. First, this study controls for the country's legal system. Civil law (CIVLAW) is a dummy variable that takes the value 1 if the firm operates in a civil law country and 0 otherwise. Furthermore, this study controls for the presence of a corporate social responsibility committee (CSRCOM). This dummy variable assumes a value of 1 if the firm has a corporate social responsibility committee and 0 in the opposite case. It also controls for firm profitability (ROE) and firm size (FSIZE). In addition, following Vitolla et al. (2020c), it controls for firm age (AGE). This variable is calculated as the difference between 2019 and the founding year of the company. Finally, this study controls for the industry environmental sensitivity (IES). This dummy variable assumes a value of 1 if the firm operates in a highly polluting sector and 0 otherwise.

To test the hypotheses, this study uses a regression model. Specifically, the model of analysis that this study proposes is reflected in this equation:

$$
\begin{gathered}
\text { IRAL }=\beta_{0}+\beta_{1} \mathrm{BS}+\beta_{2} \mathrm{BAA}+\beta_{3} \mathrm{BGD}+\beta_{4} \mathrm{DUAL}+\beta_{5} \mathrm{CIVLAW}+\beta_{6} \mathrm{CSRCOM}+\beta_{7} \mathrm{ROE}+\beta_{8} \mathrm{FSIZE}+ \\
\beta_{9} \mathrm{AGE}+\beta_{10} \mathrm{IES}+\varepsilon
\end{gathered}
$$

\section{Results}

\subsection{Descriptive Analysis and Correlation Analysis}

Table 1 presents descriptive statistics and correlation analysis. With reference to the descriptive statistics, the level of alignment with the IIRC framework (IRAL), that represents our dependent variable, has an average value equal to 21.27. Considering that the maximum obtainable score is 30, it's clear that the integrated reports of selected companies have on average a high level of alignment with the IIRC framework. The boards of the selected companies are composed on average of about 12 members and have a board average age of about 51 years. The gender diversity board has an average value of $22.73 \%$ while in about half of the companies the CEO is also chairman of the board.

With reference to the second element, the strongest correlation is found between integrated reporting alignment level and board gender diversity (0.253). This value shows th absence of multicollinearity problems (Farrar \& Glauber, 1967). We also controlled multicollinearity through the variance inflator factor (VIF) analysis. The findings show the absence of multicollinearity since the VIFs ranged from 1.03 (BAA) to 1.32 (BS). VIFs less than 10 do not generate multicollinearity problems (Myers, 1990).

Table 1. Descriptive statistics and correlation analysis

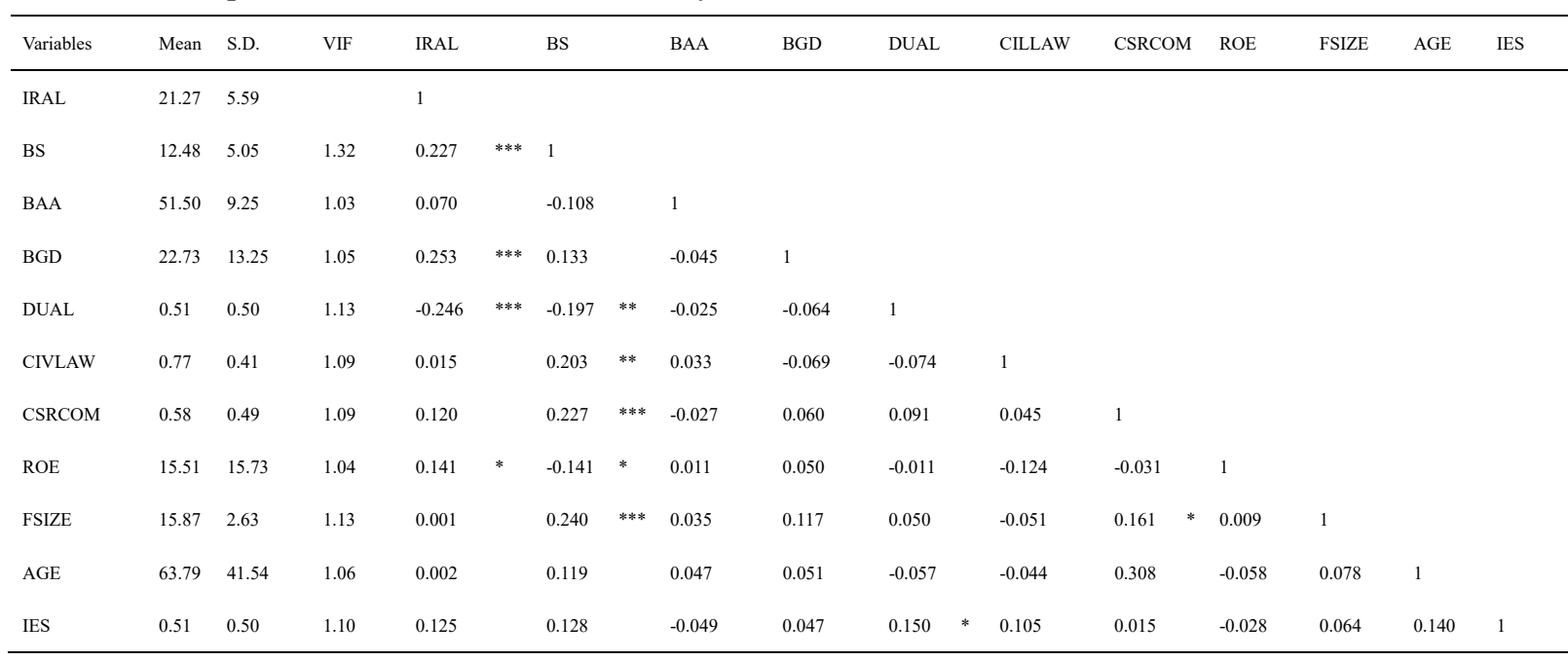

Note. $n=139$. S.D. $=$ Standard Deviation. $\quad * * *=$ significant at the $1 \%$ level; $* *=$ significant at the $5 \%$ level; $*=$ significant at the $10 \%$ level. 


\subsection{Results of the Hypotheses Tests}

Table 2 presents the results of the regression model.

The findings support hypothesis 1 . In fact, they show a positive and significant effect of board size (BS) on the level of alignment with the IIRC framework (IRAL) at $\mathrm{p}=0.056$. This shows that companies with a greater number of directors on the board are more likely to draw up an integrated report more aligned with the IIRC requirements.

The results also support hypothesis 3 . In fact, they show a positive and significant effect of board gender diversity (BGD) on the level of alignment with the IIRC framework (IRAL) at $\mathrm{p}=0.009$. This shows that companies with more women on the board are more likely to draw up an integrated report more aligned with the IIRC requirements.

Furthermore, the results also support hypothesis 4 . In fact, they show a negative and significant effect of CEO duality (DUAL) on the level of alignment with the IIRC framework (IRAL) at $\mathrm{p}=0.007$. This shows that companies in which the CEO is not chairman of the board are more likely to draw up an integrated report more aligned with the IIRC requirements.

Hypothesis 2, on the other hand, is not supported by the results. In fact, they show an insignificant relationship between board average age (BAA) and the level of alignment with the IIRC framework (IRAL).

As regards the control variables, the findings show a positive effect of firm profitability (ROE), firm size (FSIZE) and industry environmental sensitivity (IES) on the level of alignment with the IIRC framework (IRAL), respectively at $\mathrm{p}=0.060, \mathrm{p}=0.000$ and $\mathrm{p}=0.086$.

Table 2. Hypotheses tests

\begin{tabular}{lllll}
\cline { 2 - 4 } Variables & Coefficient & Standard error & p-value \\
\hline Cons & 15.462 & 3.893 & $0.000^{* * *}$ \\
BS & 0.194 & 0.100 & $0.056^{* *}$ \\
BAA & 0.065 & 0.048 & 0.180 \\
BGD & 0.087 & 0.034 & $0.009 * * *$ \\
DUAL & -2.545 & 0.933 & $0.007^{* *}$ \\
CIVLAW & -0.441 & 1.102 & 0.689 \\
CSRCOM & 1.223 & 0.931 & 0.191 \\
ROE & 0.054 & 0.285 & $0.060^{* *}$ \\
FSIZE & 0.138 & 0.077 & $0.000^{* * *}$ \\
AGE & -0.007 & 0.010 & 0.467 \\
IES & 1.595 & 0.922 & $0.086^{*}$ \\
N & 139 & & \\
Adj. ${ }^{2}$ & 0.246 & & \\
Note. $* * *$ significant at the $1 \%$ level $; * *$ significant at the $5 \%$ level; $*=$ significant at the $10 \%$ level.
\end{tabular}

\section{Discussion and conclusions}

This research aimed to analyse the role of corporate governance variables in integrated reporting policies. Specifically, it analysed the effect of some characteristics of the board and the CEO on the level of alignment of integrated reporting with the IIRC framework. The results show, firstly, the presence of a high level of alignment of the integrated reports analysed with the IIRC requirements and, secondly, a positive effect of the board size and board gender diversity and a negative effect of the CEO duality on the level of compliance with the IIRC framework.

The high level of alignment with the IIRC framework is linked to the completeness and simplicity of the IIRC requirements. The IIRC principles allow companies to provide interconnected information to investors and all stakeholders capable of describing a holistic framework of business management. Therefore, aligning the integrated report to the IIRC framework allows companies to provide an organic, complete, more readable and understandable report. Furthermore, compliance with the IIRC requirements increases the standardization level of the integrated reports and therefore facilitates the comparison between different companies. Finally, a greater level of alignment with the IIRC framework simplifies the search for key content for the recipients of the document. These circumstances could explain the high level of alignment of the integrated reports analysed with the IIRC 
framework.

In relation to the individual corporate governance variables, the results showed above all a positive effect of the board size and the gender diversity board on the level of alignment of the integrated reports with the IIRC framework. This can be explained by the greater control and monitoring capabilities of the boards with a greater number of directors and a greater percentage of women who could facilitate the preparation of integrated reports more aligned with the IIRC framework. The results also demonstrated a negative effect of the CEO duality on the level of alignment of integrated reports with the IIRC framework. This can be explained by the lower control and monitoring skills of the boards chaired by the CEO which could lead to the disclosure of integrated reports less aligned with the IIRC framework. The results also showed an insignificant effect of the board average age. This circumstance can be linked to the greater openness towards change and to the new ideas of the young directors who could cancel the effects of the greater experience in the control and monitoring of older directors, making the effect of the board average age on the level of alignment of the integrated reports with IIRC requirements not significant.

The results obtained have important implications for high level corporate governance bodies. In fact, they should try to form boards of directors with characteristics capable of increasing the level of transparency of companies. In this regard, they should form boards with a greater number of directors and a higher percentage of women. In fact, these circumstances, together with the absence of CEO duality, are able to increase the control and monitoring capabilities of the board and thus encourage the publication of integrated reports more aligned with the IIRC framework.

This study is subject to two methodological limitations. The first is connected to the subjectivity of the content analysis. This circumstance was mitigated by the joint analysis by the authors of the integrated reports. The second limitation is connected to the choice of the cross section instead of the panel analysis due to the little variability of the level of alignment of the integrated reports with the IIRC framework over time.

In this regard, future studies could develop different scoreboards to measure the level of compliance and carry out longitudinal analyses. Furthermore, future studies could analyse the effect of further determinants at country, firm and sector level.

\section{References}

Adams, R. B., \& Ferreira, D. (2009). Women in the boardroom and their impact on governance and performance. Journal of financial economics, 94(2), 291-309. https://doi.org/10.1016/j.jfineco.2008.10.007

Adams, R. B., Almeida, H., \& Ferreira, D. (2005). Powerful CEOs and their impact on corporate performance. The Review of Financial Studies, 18(4), 1403-1432. https://doi.org/10.1093/rfs/hhi030

Ahmed, H. A., \& Anifowose, M. (2016). Audit committee and integrated reporting practice: does internal assurance matter? Managerial Auditing Journal, 31(8/9), 915-948. https://doi.org/10.1108/MAJ-12-2015-1293

Alfiero, S., Cane, M., Doronzo, R., \& Esposito, A. (2017). Board configuration and IR adoption: Empirical evidence from European companies. Corporate Ownership \& Control, 15(1), 444-458. https://doi.org/10.22495/cocv15i1c2p13

Barth, M. E., Cahan, S. F., Chen, L., \& Venter, E. R. (2017). The economic consequences associated with integrated report quality: capital market and real effects. Accounting, Organizations and Society, 62, 43-64. https://doi.org/10.1016/j.aos.2017.08.005

Ben-Amar, W., \& Mcllkenny, P. (2015). Board effectiveness and the voluntary disclosure of climate change information. Business Strategy and the Environment, 24(8), 704-719. https://doi.org/10.1002/bse.1840

Buss, D. M. (2005). The handbook of evolutionary psychology. John Wiley \& Sons.

Cheng, E. C., \& Courtenay, S. M. (2006). Board composition, regulatory regime and voluntary disclosure. The international journal of accounting, 41(3), 262-289. https://doi.org/10.1016/j.intacc.2006.07.001

D’Este, C., Fellegara, A., Galli, D., \& di Piacenza, G. (2013). Livelli di disclosure economico-finanziaria e scelte di integrated reporting nei gruppi a connotazione territoriale. Paper presented at the XXXVI AIDEA Conference. The Firms Role in Economy. Does a Growth-Oriented Business Model Exist, 1-26. Retrieved from http://www.aidea2013.it/docs/348_aidea2013_economia-aziendale.pdf

Dahya, J., Lonie, A. A., \& Power, D. M. (1996). The case for separating the roles of chairman and CEO: An analysis of stock market and accounting data. Corporate Governance: An International Review, 4(2), 71-77. https://doi.org/10.1111/j.1467-8683.1996.tb00136.x 
Dalton, D. R., Daily, C. M., Johnson, J. L., \& Ellstrand, A. E. (1999). Number of directors and financial performance: A meta-analysis. Academy of Management Journal, 42(6), 674-686. https://doi.org/10.2307/256988

Esch, M., Schnellbächer, B., \& Wald, A. (2019). Does integrated reporting information influence internal decision making? An experimental study of investment behavior. Business Strategy and the Environment, 28(4), 599-610. https://doi.org/10.1002/bse.2267

Fama, E. F., \& Jensen, M. C. (1983). Agency problems and residual claims. The journal of law and Economics, 26(2), 327-349. https://doi.org/10.1086/467038

Farrar, D. E., \& Glauber, R. R. (1967). Multicollinearity in regression analysis: the problem revisited. The Review of Economic and Statistics, 92-107. https://doi.org/10.2307/1937887

Fasan, M., \& Mio, C. (2017). Fostering stakeholder engagement: The role of materiality disclosure in integrated reporting. Business Strategy and the Environment, 26(3), 288-305. https://doi.org/10.1002/bse.1917

Feingold, A. (1994). Gender differences in personality: A meta-analysis. Psychological bulletin, 116(3), 429-456. https://doi.org/10.1037/0033-2909.116.3.429

Finkelstein, S., \& D'Aveni, R. A. (1994). CEO duality as a double-edged sword: How boards of directors balance entrenchment avoidance and unity of command. Academy of Management journal, 37(5), 1079-1108. https://doi.org/10.5465/256667

Frías-Aceituno, J. V., Rodriguez-Ariza, L., \& Garcia-Sanchez, I. M. (2013b). The role of the board in the dissemination of integrated corporate social reporting. Corporate Social Responsibility and Environmental Management, 20(4), 219-233. https://doi.org/10.1002/csr.1294

Frías-Aceituno, J. V., Rodríguez-Ariza, L., \& Garcia-Sánchez, I. M. (2014). Explanatory factors of integrated sustainability and financial reporting. Business Strategy and the Environment, 23(1), 56-72. https://doi.org/10.1002/bse.1765

Frías-Aceituno, J. V., Rodríguez-Ariza, L., \& García-Sánchez, I. M. (2013a). Is integrated reporting determined by a country's legal system? An exploratory study. Journal of Cleaner Production, 44, 45-55. https://doi.org/10.1016/j.jclepro.2012.12.006

Gandía, J. L. (2008). Determinants of internet-based corporate governance disclosure by Spanish listed companies. Online Information Review, 32(6), 791-817. https://doi.org/10.1108/14684520810923944

García-Sánchez, I. M., \& Noguera-Gámez, L. (2018). Institutional investor protection pressures versus firm incentives in the disclosure of integrated reporting. Australian Accounting Review, 28(2), 199-219. https://doi.org/10.1111/auar.12172

Gerwanski, J., Kordsachia, O., \& Velte, P. (2019). Determinants of materiality disclosure quality in integrated reporting: Empirical evidence from an international setting. Business Strategy and the Environment, 28(5), 750-770. https://doi.org/10.1002/bse. 2278

Giannarakis, G. (2014). The determinants influencing the extent of CSR disclosure. International Journal of Law and Management, 56(5), 393-416. https://doi.org/10.1108/IJLMA-05-2013-0021

Gul, F. A., \& Leung, S. (2004). Board leadership, outside directors' expertise and voluntary corporate disclosures. Journal of Accounting and public Policy, 23(5), 351-379. https://doi.org/10.1016/j.jaccpubpol.2004.07.001

Haniffa, R. M., \& Cooke, T. E. (2002). Culture, corporate governance and disclosure in Malaysian corporations. Abacus, 38(3), 317-349. https://doi.org/10.1111/1467-6281.00112

Healy, J. (2002). Corporate governance \& wealth creation in New Zealand. Palmerston North: Dunmore Press Ltd.

Hidalgo, R. L., García-Meca, E., \& Martínez, I. (2011). Corporate governance and intellectual capital disclosure. Journal of Business Ethics, 100(3), 483-495. https://doi.org/10.1007/s10551-010-0692-x

Ho, S. S., \& Wong, K. S. (2001). A study of the relationship between corporate governance structures and the extent of voluntary disclosure. Journal of International Accounting, Auditing and Taxation, 10(2), 139-156. https://doi.org/10.1016/S1061-9518(01)00041-6

Hofstede, G., Hofstede, G. J., \& Minkov, M. (2010). Cultures and organizations: Software of the mind: Intercultural operation and its importance for survival (3rd ed.). McGraw-Hill: New York, NY.

Huse, M., \& Solberg, A. (2006). Gender-related boardroom dynamics: How Scandinavian women make and can 
make contributions on corporate boards. Women in Management Review, 21(2), 113-130. https://doi.org/10.1108/09649420610650693

IIRC. (2013). International <IR> Framework. Retrieved from http://www.integratedreporting.org

Izzo, M. F., \& Fiori, G. (2016). The influence of corporate governance on the adoption of the integrated report: A first study on IIRC pilot programme. In Integrated reporting (pp. 155-179). Palgrave Macmillan, London. https://doi.org/10.1057/978-1-137-55149-8_9

Jensen, J. C., \& Berg, N. (2012). Determinants of traditional sustainability reporting versus integrated reporting. An institutionalist approach. Business Strategy and the Environment, 21(5), 299-316. https://doi.org/10.1002/bse.740

Jensen, M. C., \& Meckling, W. H. (1976). Theory of the firm: Managerial behavior, agency costs and ownership structure. Journal of Financial Economics, 3(4), 305-360. https://doi.org/10.1016/0304-405X(76)90026-X

Kilic, M., \& Kuzey, C. (2018). Determinants of forward-looking disclosures in integrated reporting. Managerial Auditing Journal, 33(1), 115-144. https://doi.org/10.1108/MAJ-12-2016-1498

Kosnik, R. D. (1990). Effects of board demography and directors' incentives on corporate greenmail decisions. Academy of Management journal, 33(1), 129-150. https://doi.org/10.2307/256355

Krishnan, G., \& Visvanathan, G. (2009). Do auditors price audit committee's expertise? The case of accounting versus nonaccounting financial experts. Journal of Accounting, Auditing \& Finance, 24(1), 115-144. https://doi.org/10.1177/0148558X0902400107

Lai, A., Melloni, G., \& Stacchezzini, R. (2016). Corporate sustainable development: Is "integrated reporting" a legitimation strategy? Business Strategy and the Environment, 25(3), 165-177. https://doi.org/10.1002/bse.1863

Larmou, S., \& Vafeas, N. (2010). The relation between board size and firm performance in firms with a history of poor operating performance. Journal of Management \& Governance, 14(1), 61. https://doi.org/10.1007/s10997-009-9091-z

Marrone, A., \& Oliva, L. (2019). Measuring the Level of Integrated Reporting Alignment with the < IR> Framework. International Journal of Business and Management, 14(12), 110-120. https://doi.org/10.5539/ijbm.v14n12p110

Marrone, A., \& Oliva, L. (2020). The Level of Integrated Reporting Alignment with the IIRC Framework: Evidence from South Africa. International Journal of Business and Management, 15(1), 99-108. https://doi.org/10.5539/ijbm.v15n1p99

Melloni, G., Caglio, A., \& Perego, P. (2017). Saying more with less? Disclosure conciseness, completeness and balance in Integrated Reports. Journal of Accounting and Public Policy, 36(3), 220-238. https://doi.org/10.1016/j.jaccpubpol.2017.03.001

Mervelskemper, L., \& Streit, D. (2017). Enhancing market valuation of ESG performance: Is integrated reporting keeping its promise? Business Strategy and the Environment, 26(4), 536-549. https://doi.org/10.1002/bse.1935

Muttakin, M. B., Khan, A., \& Mihret, D. G. (2018). The effect of board capital and CEO power on corporate social responsibility disclosures. Journal of Business Ethics, 150(1), 41-56. https://doi.org/10.1007/s10551-016-3105-y

Myers, R. H. (1990). Classical and modern regression with applications. Second edition. Belmont, CA: Duxbury.

Parum, E. (2005). Does disclosure on corporate governance lead to openness and transparency in how companies are managed? Corporate Governance: An International Review, 13(5), 702-709. https://doi.org/10.1111/j.1467-8683.2005.00461.x

Pearce, J. A., \& Zahra, S. A. (1992). Board composition from a strategic contingency perspective. Journal of management studies, 29(4), 411-438. https://doi.org/10.1111/j.1467-6486.1992.tb00672.x

Perrini, F. (2006). The practitioner's perspective on non-financial reporting. California Management Review, 48(2), 73-103.

Pfeffer J., \& Salancik, G. R. (1978). The External Control of Organizations: A Resource Dependency Perspective, New York, Harper and Row.

Pfeffer, J. (1972). Size and composition of corporate boards of directors: The organization and its environment. 
Administrative science quarterly, 218-228. https://doi.org/10.2307/2393956

Porter, M. E., \& Kramer, M. R. (2011). The Big Idea: Creating Shared Value. How to reinvent capitalism—and unleash a wave of innovation and growth. Harvard Business Review, 89(1-2).

Post, C., Rahman, N., \& Rubow, E. (2011). Green governance: Boards of directors' composition and environmental corporate social responsibility. Business \& Society, 50(1), 189-223. https://doi.org/10.1177/0007650310394642

Raimo, N., Zito, M., \& Caragnano, A. (2019). Does national culture affect integrated reporting quality? A focus on GLOBE dimensions. In 9th International Symposium on Natural Resources Management, Zaječar, Serbia.

Srinidhi, B. I. N., Gul, F. A., \& Tsui, J. (2011). Female directors and earnings quality. Contemporary Accounting Research, 28(5), 1610-1644. https://doi.org/10.1111/j.1911-3846.2011.01071.x

Stacchezzini, R., Melloni, G., \& Lai, A. (2016). Sustainability management and reporting: the role of integrated reporting for communicating corporate sustainability management. Journal of Cleaner Production, 136, 102-110. https://doi.org/10.1016/j.jclepro.2016.01.109

Tuggle, C. S., Sirmon, D. G., Reutzel, C. R., \& Bierman, L. (2010). Commanding board of director attention: investigating how organizational performance and CEO duality affect board members' attention to monitoring. Strategic management journal, 31(9), 946-968. https://doi.org/10.1002/smj.847

Useem, M. (1993). Executive defense: Shareholder power and corporate reorganization. Harvard University Press.

Vitolla, F., \& Raimo, N. (2018). Adoption of integrated reporting: Reasons and benefits-A case study analysis. International Journal of Business and Management, 13(12), 244-250 https://doi.org/10.5539/ijbm.v13n12p244

Vitolla, F., Raimo, N., \& De Nuccio, E. (2018). Integrated Reporting: Development and State of Art - The Italian Case in the International Context. International Journal of Business and Management, 13(11), 233-240. https://doi.org/10.5539/ijbm.v13n11p233

Vitolla, F., Raimo, N., \& Rubino, M. (2019a). Intellectual Capital Disclosure and Firm Performance: An Empirical Analysis through Integrated Reporting. In 7th International OFEL Conference, Dubrovnik, Croatia.

Vitolla, F., Raimo, N., \& Rubino, M. (2019c). Appreciations, criticisms, determinants, and effects of integrated reporting: A systematic literature review. Corporate Social Responsibility and Environmental Management, 26(2), 518-528. https://doi.org/10.1002/csr.1734

Vitolla, F., Raimo, N., \& Rubino, M. (2020b). Board characteristics and integrated reporting quality: an agency theory perspective. Corporate Social Responsibility and Environmental Management, 27(2), 1152-1163. https://doi.org/10.1002/csr.1879

Vitolla, F., Raimo, N., Rubino, M., \& Garzoni, A. (2019b). How pressure from stakeholders affects integrated reporting quality. Corporate Social Responsibility and Environmental Management, 26(6), 1591-1606. https://doi.org/10.1002/csr.1850

Vitolla, F., Raimo, N., Rubino, M., \& Garzoni, A. (2019d). The impact of national culture on integrated reporting quality. A stakeholder theory approach. Business Strategy and the Environment, 28(8), 1558-1571. https://doi.org/10.1002/bse.2332

Vitolla, F., Raimo, N., Rubino, M., \& Garzoni, A. (2020c). The determinants of integrated reporting quality in financial institutions. Corporate Governance: The International Journal of Business in Society. https://doi.org/10.1108/CG-07-2019-0202

Vitolla, F., Salvi, A., Raimo, N., Petruzzella, F., \& Rubino, M. (2020a). The impact on the cost of equity capital in the effects of integrated reporting quality. Business Strategy and the Environment, 29(2), 519-529. https://doi.org/10.1002/bse.2384

Watson, E., Kumar, K., \& Michaelsen, L. (1993). Cultural diversity's impact on interaction process and performance: Comparing homogeneity and diverse task groups. Academy of Management Journal, 36, 590-603. https://doi.org/10.2307/256593

Westphal, J. D., \& Milton, L. P. (2000). How experience and network ties affect the influence of demographic minorities on corporate boards. Administrative Science Quarterly, 45(2), 366-398. https://doi.org/10.2307/2667075 


\section{Copyrights}

Copyright for this article is retained by the author(s), with first publication rights granted to the journal.

This is an open-access article distributed under the terms and conditions of the Creative Commons Attribution license (http://creativecommons.org/licenses/by/4.0/). 